\title{
INSECTS
}

\section{CHECKLIST OF SASKATCHEWAN MOTHS: PART 16 - GEOMETRIDS (2), ENNOMINAE (2).}

RONALD R. HOOPER, Box 757, Fort Qu'Appelle, SK SOG 1S0

This is a continuation of the list of Saskatchewan geometrid moths in the subfamily Ennominae. The first geometrid article was published in Blue Jay, volume 64, number 2.

Unless otherwise indicated, all the species are represented in the Royal Saskatchewan Museum collection in Regina. The species are arranged according to the website of Jim Troubridge and Don Lafontaine, The Moths of Canada, ${ }^{8}$ with updates to 2006 provided to the author by Greg Pohl. This website also has colour photographs of the moths. McGuffin's well-illustrated Guide to Geometridae of Canada covers the portion of the Ennominae subfamily in this list. $^{3,4,5}$ This reference is the source of much of the information presented here but the preferred food plants listed are primarily based on Prentice. ${ }^{6}$ The common names that are used are mostly according to R. J. L. Jones and C. V. Covell, Jr. Recent scientific name changes are according to $M$. J. Scoble. ${ }^{1,2,7}$

In this article, the size and early and late dates of Saskatchewan specimens are given. Some of the recorded food plants are mentioned. Abbreviations: $\mathrm{s}=$ south, $\mathrm{n}=$ north $\mathrm{w}=$ west, and $\mathrm{e}=$ east, $\mathrm{CNC}=$ Canadian National Collection, in Ottawa.

\section{Subfamily ENNOMINAE}

This is the largest subfamily of geometrid moths in Canada. It contains our largest geometrid moths (up to $48 \mathrm{~mm}$ in wingspan) as well as medium-sized ones. The males usually have a blister-like structure at the base of the fore-wings between the veins. In a few species the females are wingless, or have greatly reduced wings.

\section{Transcanada}

Orthofidonia Orthofidonia exornata (Walker) Greenwater Provincial Park and Kinistino area. $(27 \mathrm{~mm}$ ) (June 11) Reported on bush cranberry.

\section{Yellow-veined Orthofidonia} Orthofidonia flavivenata (Hulst) Bainbridge (n. of Hudson Bay). Formerly reported west to Cochrane, Ontario by McGuffin. ${ }^{3}$ One Manitoba specimen is in the Wallis collection, taken at Manitoba Cultural College, Winnipeg. June 15, 1921, by N. Pankiw. (28-33 $\mathrm{mm}$ ) (May 17).

Large Sulphur Hesperumia sulphuraria Pack. - S. Sask., n. to Key Lake. (28-33 mm) (June 28-Aug. 14) Reported to be a general feeder.

Cranberry Spanworm Ematurga amitaria (Gn.) - S. Sask., n. to Love and Harlan. (24-27 mm) (June 2- July 1) 
Reported on bog cranberry, meadowsweet and raspberry.

\section{Oak Carpet Stenoporpia} polygrammaria (Pack.) - Spy Hill, Tantallon and Stockholm. (23-29 mm) (July 5-13) Reported on oak.

Four-barred Gray Aethalura intertexta (Walker) - Central Sask., n. to Buffalo Narrows, s. to Douglas Park and Harlan. (22-23 mm) (June 6-26) Reported on alder and birch.

Large Purplish Gray Iridopsis vellivolata (Hulst) (=Anacamptodes vellivolata) - Reported from centraleastern Sask., w. to Prince Albert; also Roche Percee area. $(30-32 \mathrm{~mm})$ Reported on jack pine.

Pale-winged Gray Iridopsis ephyraria (Walker) (=Anacamptodes ephyraria) - S. Sask., n. to Deschambault Lake. (29 mm) (July 2026) Reported on birch, alder, willow and maple.

Bent-lined Gray Iridopsis larvaria (Gn.) - S. Sask., n. to Otter Rapids- (28$31 \mathrm{~mm}$ ) (May 31- Aug. 21) Reported on birch, alder, willow and aspen.

Cranberry Spanworm Anavitrinelia pampinaria (Gn.) - S. Sask., n. to Narrow Hills Provincial Park, Waskesiu area and Harlan area. (27-31 mm) (June 1July 30 ) Reported on bush cranberry, buffaloberry, birch and willow.

\section{Twilight Carpet Ectropis} crepuscularia (D. \& S.) - S. Sask. n. to Otter Rapids- (31-36 mm) (May 14- July 1) Reported on fir, tamarack, spruce, willow and many other trees and shrubs.

Speckled Carpet Protoboarmia procelaria (Gn.) - Central Sask., n. to
Sturgeon Landing, Waskesiu area and Meadow Lake Provincial Park area, s to Roche Percee, Fort Qu'Appelle and Outlook. Also in Cypress Hills. (31-33 $\mathrm{mm}$ ) (May 29-July 7) Reported on fir, spruce, tamarack, pine, birch and aspen.

Pine Powder Moth Eufidonia convergaria (Walker) - N. Sask., s. to Greenbush, Prince Albert and Meadow Lake Provincial Park. (20-25 mm) (May 29-July 15) Reported on pine.

Powder Moth Eufidonia notataria (Walker) - Reported for Sask. by Troubridge and Lafontaine. ${ }^{8}$ Reported on spruce, fir and tamarack.

Sharp-lined Powder Moth Eufidonia discospilata (Walker) - N. Sask., s. to Crooked Lake, Prince Albert and Harlan area. (20-23 mm) (June 11-July 12) Reported on bog myrtle, rosemary, Labrador tea, cranberry and birch.

\section{Canadian}

Melanolophia Melanolophia canadaria (Gn.) - S. Sask., n. to Beaver Lake area and Turtle Lake area. (32-33 mm) (May 17- July 1) Reported on birch and willow.

Signate Melanolophia Melanolophia signataria (Walker) - S. e. Sask., n. to Bainbridge and Candle Lake. (31-35 $\mathrm{mm}$ ) (May 24-June 21) Reported on birch and fir.

Pepper and Salt Moth Biston betularia cognataria (Gn.) - S. Sask., n. to Sturgeon Landing, Turtle Lake and Onion Lake. (42-52 mm) (June 22-July 27) Reported on willow, birch, alder, tamarack and aspen.

The Bear Lycia ursaria (Walker) Central Sask, n. to Red Earth, Prince Albert area and Meadow Lake Provincial Park area; s. to Regina and 
Moose Jaw. (38-43 mm - males) (April 16- May 29) Reported on birch, willow and alder.

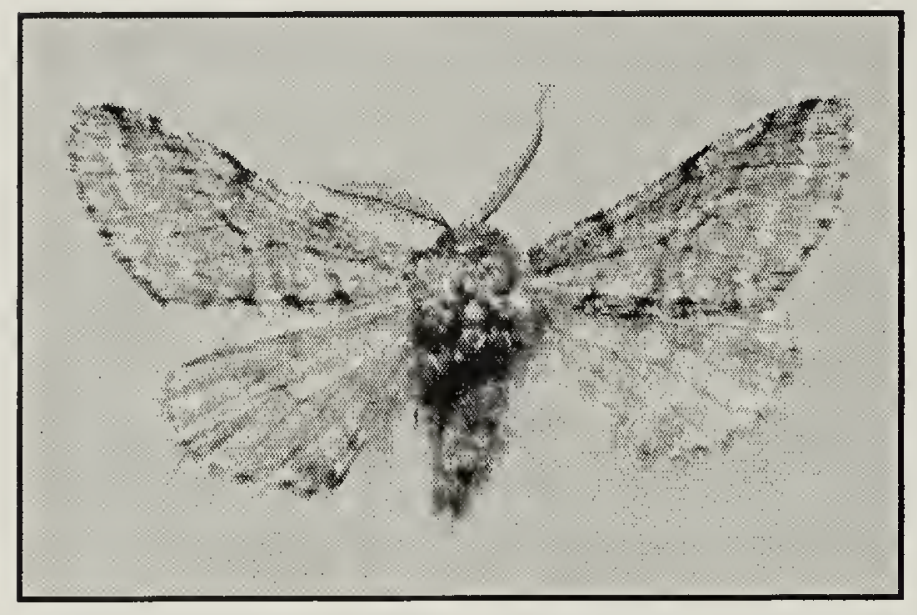

The Bear

RSM collection, Keith Roney

Rachel's Moth Lycia rachelae (Hulst) - S. Sask., n. to Waskesiu area and Meadow Lake area. (26-36 mm males) (April 6- June 4) Reported on willow, buffaloberry and birch.

One-spotted Variant Hypagyrtis unipunctata (Haw.) - S. Sask., n. to Gronlid area. (28-35 mm) (June 2-July 18) Reported on rose, Saskatoon, willow and chokecherry.

Pine Measuring Worm Moth Hypagyrtis piniata (Pack.) - Central Sask., n. to Nipawin area and Meadow Lake area; s. to Kamsack area and Saint Louis area. Reported on fir, spruce, tamarack and pine.

Half Wing (Spiny Looper) Phigalea titea (Cram.) - Lestock, Fort Qu'Appelle, Regina, Moose Jaw and Buffalo Pound Provincial Park. (34-40 mm - males) (April 21-May 2) Reported on elm, birch, oak and willow.

\section{Spring Cankerworm Paleacrita} vernata (Peck) - S. Sask., n. to Prince Albert area. (22-28 mm - males) (April 4- May 30) Reported on elm, birch and chokecherry.
Lime-tree Looper Erannis tiliaria (Harr.) - S. Sask., n. to Red Earth, Weldon area and Lloydminster area. (37-45 mm - males) (Sept. 2- Oct. 15) Reported on elm, birch and aspen.

\section{Mottled Umber Erannis} vancouverensis Hulst - Reported from Macklin by McGuffin.

Clouded View Lomographa semiclarata (Walker) - S. Sask., n. to Greenbush, Love and lle a la Crosse. (18-22 mm) (May 8- June 18) Reported on cherry, hawthorn and mountain ash.

White Spring Moth Lomographa vestaliata (Gn.) - Gainsborough, Roche Percee, Maryfield and Tantallon. (16-19 $\mathrm{mm}$ ) (June 2-14) Reported on cherry, hawthorn and mountain ash.

Northern Wave Cabera exanthemata bryantaria (Taylor) Patterson Lake (n. e. Sask.), Hunt Falls and Cypress Hills. (26-30 mm) (June 14-30) Reported on willow.

Yellow-dusted Cream Moth Cabera erythemaria Gn. - Throughout Sask. (21-28 mm) (June 1- Aug. 20) Reported on willow.

The Vestal Cabera variolaria Gn. Throughout Sask. (21-27 mm) (May 31Sept. 13) Reported on willow and aspen.

Dark Cabera Cabera borealis (Hulst) - Patterson Lake (n. e. Sask.), Hunt Falls and Big River. (22-24 mm) (June 13-30) Reported on willow, aspen and birch.

Obtuse Thorn Euchlaena obtusaria (Hbn.) - S. Sask., n. to Preeceville, Tisdale and Loon Lake. (35-40 mm) (May 21- July 13) Reported on touchme-not. 
Least-marked Thorn Euchlaena irraria (B. \& McD.) - Crooked Lake, Fort Qu'Appelle, St. Victor, Buffalo Pound Provincial Park and Outlook. (38-41 $\mathrm{mm}$ ) (June 2- July 2) Reported on dogwood, meadowsweet, birch, aspen and oak.

Pale-tipped Thorn Euchlaena madusaria (Wlk.) - Throughout Sask. (30-38 mm) (June 19-July 24) Reported on pine, buffaloberry and blueberry.

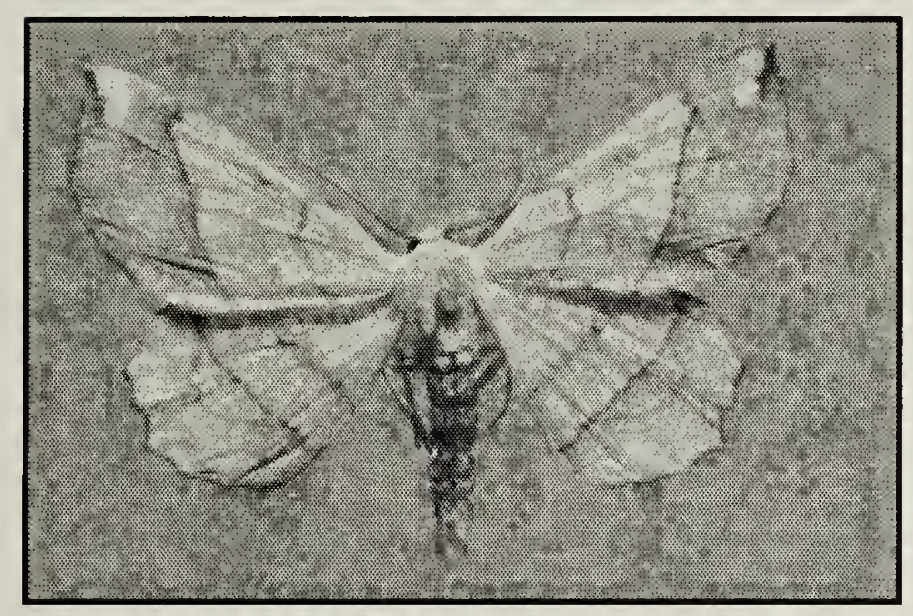

Pale-tipped Thorn

RSM collection, Keith Roney

Johnson's Thorn Euchlaena johnsonaria (Fitch) - S. Sask., n. to Greenbush, Fort a la Corne area and Loon Lake. (32-36 mm) (June 15-Aug. 2) Reported on dogwood, meadowsweet, elm, birch, ash and chokecherry.

Variable Thorn Euchlaena tigrinaria (Gn.) - S. Sask., n. to Cumberland House and La Ronge. (36-38 mm) (June 16-Aug. 9) Reported on buffaloberry, pine, birch, willow and aspen.

Scalloped Thorn Euchlaena effecta (Walker) - Tantallon. (36-40 mm) (June 25-July 3) Reported on dogwood, meadowsweet, blueberry, ash and chokecherry.

Alberta Thorn Euchlaena marginaria (Minot) - S. Sask., n. to
Greenbush and lle a la Crosse- $35-40$ $\mathrm{mm}$ ) (May 15- June 21) Reported on birch, elm, willow, meadowsweet and dogwood.

Crocus Geometer Xanthotype sospeta (Drury) - S. Sask, n. to Cumberland House and Otter Rapids. (35-45 mm) (June 21- July 11) Reported on meadowsweet, willow and blueberry.

False Crocus Geometer Xanthotype urticaria (Swett.) - S. Sask., n. to Deschambault Lake and Meadow Lake Provincial Park. (30- $35 \mathrm{~mm}$ ) (June 21July 10) Reported on meadowsweet, goldenrod, rose and currant.

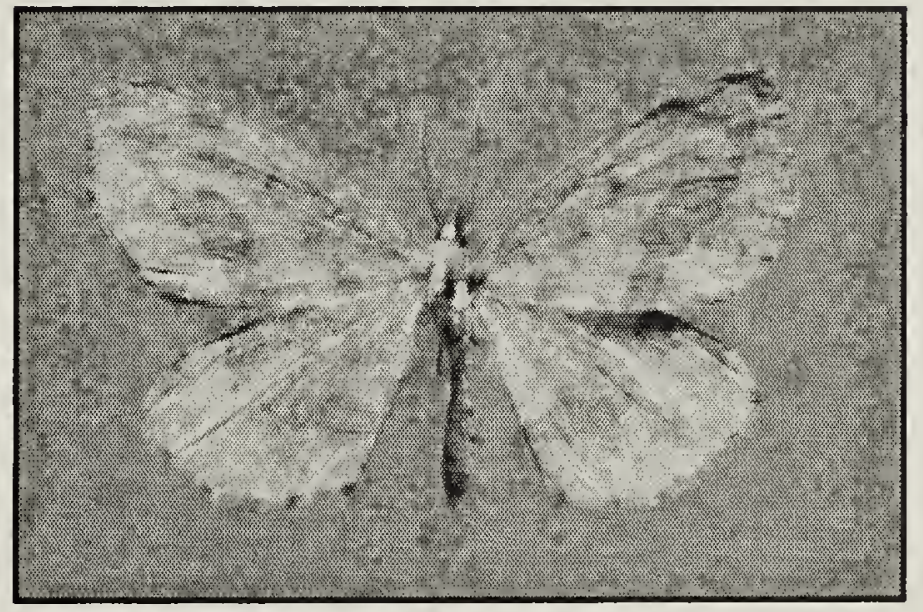

False Crocus Geometer

RSM collection, Keith Roney

Prairie Aspitates Aspitates aberrata (Hy. Edw.) - S. Sask., n. to Kamsack, Fulda and Battleford. (24-35 mm) (May 16- July 24) On dry prairie.

Bog Aspitates Aspitates taylori (Butl.) - Hasbala Lake, Patterson Lake (n.e. Sask.), junction of Hwy 155 and Hwy 908, and Salt Creek (n. of Flotten Lake)(27-33 mm) (June 14-July 2) In cranberry bogs.

Honest Pero Pero honestaria (Walker) - S. Sask., n. to Shoal Lake and Onion Lake. (33-39 mm) (May 29July 23) Reported on cherry. 
Morrison's Pero Pero morrisonaria (Hy. Edw.) - S. Sask., n. to Sturgeon Landing and La Ronge. (32-40 mm) (May 27-Aug. 16) Reported on fir, spruce, willow, tamarack, birch, meadowsweet and buffaloberry.

Oak Beauty Phaeoura quernaria (Sm.) (=Nacrophora quernaria) Broadview, Goodeve, Punnichy and Birch Hills area. (40-45 mm) (June 25July 11) Reported on birch, willow, oak and poplar.

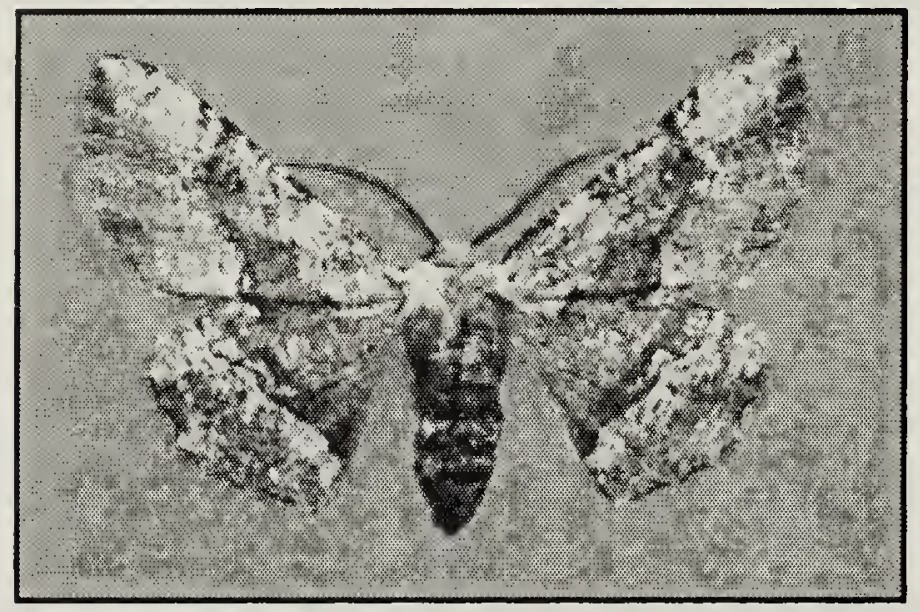

Oak Beauty

RSM collection, Keith Roney

Hardwick's Geometer Animomyia hardwicki Rindge - 1 mile s. of Beverley collected by D. F. Hardwick, Aug. 22, 1968. This is so far the only known specimen of this species. It is in CNC.

Pale Emerald Campaea perlata (Gn.) - Throughout Sask., (32-45 mm) (June 11-Aug. 12) Reported on aspen, willow and birch.

\section{Elm Spanworm Ennomos} subsignaria (Hbn.) - Roche Percee and Fort Qu'Appelle. (32-35 mm) Reported on elm, birch, ash and aspen.

\section{Notch Wing (Maple Spanworm)} Ennomos magnaria Gn. - S. Sask., n. to Creighton and La Ronge area. (40$50 \mathrm{~mm}$ ) (July 8-Oct. 2) Reported on birch, aspen and maple.
Handsome Geometer Spodolepis substriataria Hulst (=Epirranthis substriataria) - Bjorkdale and Harlan area. (43 mm) (May 7) Reported on pine, spruce and willow.

Northern Petrophora Petrophora subaequaria (Walker) - Reported for Sask. by Troubridge and Lafontaine. ${ }^{8}$ Formerly west to Red Rock Lake, Manitoba. Reported on bracken fern.

Dull Brown Tacparia Tacparia detersata (Gn.) - Tantallon and Sturgeon Landing (25 mm) (June 14) Reported on alder and larch.

Pale Homochlodes Homochlodes fritillaria (Gn.). - Bainbridge (n. of Hudson Bay) (26 mm) (May 17) Reported on ferns.

Brown-tipped Thorn Selenia alciphearia Walker. - N. Sask., s. to Moose Mountain Provincial Park and Moose Jaw. (38-47 mm) (May 2-July 8) Reported on willow, alder and birch.

Kent's Geometer Selenia kentaria (G. \& R) - Katepwa, Fort Qu'Appelle, Indian Head and Big River. (42 mm) (June 1) Reported on Elm.

Yellow-lined Thorn Metanema inatomaria Gn. - Throughout Sask., (28-38 mm) (May 31- July 19) Reported on aspen, balsam poplar and willow.

Dark-banded Thorn Metanema determinata Walker - S. Sask, n. to Cumberland House and Buffalo Narrows. (25-30 mm) (May 14- July 19) Reported on willow, aspen and ash.

Warner's Thorn Metarranthis warneri cappsaria (Rup.) - Central Sask., n. to Kamsack and Harlan area; s. to Fort Qu'Appelle and Earl Grey. (30-32 mm) 
(June 14-27) Reported on willow, cherry and dogwood.

Canadian Thorn Metarranthis duaria (Gn.) - S. Sask., n. to Sturgeon Landing, Otter Rapids and Clearwater River. (31$38 \mathrm{~mm}$ ) (May 14- July 5) Reported on chokecherry, hawthorn, meadowsweet, Saskatoon and rose.

Common Metarranthis Metarranthis mestusata (Walker) (=Metarranthis hypocharia (H. -S.) - Moose Mountain Provincial Park, Tantallon, Kamsack, Greenwater Provincial Park and Nisbet Forest. (30-34 mm) (May 31- June 25) Reported on cherry and blueberry.

Barred Umber Plagodis pulveraria (L.) (=Anagoga occiduaria (Walker)) Central Sask., n. to Bainbridge, Candle Lake, Eau Clair Lake and Harlan area; s. to Moose Mountain Provincial Park and Fort Qu'Appelle. (27-35 mm) (May 15- June 27) Reported on alder, birch, spruce and willow.

Straight-lined Plagodis Plagodis phlogosaria (Gn.) - S. Sask., n. to Greenwater Provincial Park, Candle Lake area and Primrose Lake area. (30-32 mm) (May 25- June 21) Reported on birch, alder and willow.

Hollow-spotted Plagodis Plagodis alcoolaria (Gn.) - Throughout Sask. (32 $\mathrm{mm}$ ) (June 4- July 5) Reported on birch, alder and willow.

Lemon Plagodis Plagodis serinaria H.-S. - Reported for La Ronge area by McGuffin ${ }^{5}$ and Prentice. ${ }^{6}$

Alien Probole Probole alienaria H.S. - Central Sask., n. to Sturgeon Landing; s. to Tantallon and Earl Gray. (23-28 mm) (June 11- July 14).
Sharp-toothed Thorn Probole amicaria (H.-S.) - Throughout Sask., (23-32 mm) (May 14- July 10) Reported on birch, alder and willow.

Chain-dotted Geometer Cingilia catenaria (Drury) - Somme, Bainbridge (n. of Hudson Bay), Red Earth and Sturgeon Landing. (33-42 mm) (Aug. 30- Sept. 8) Reported on spruce, fir, tamarack, birch, pine and aspen.

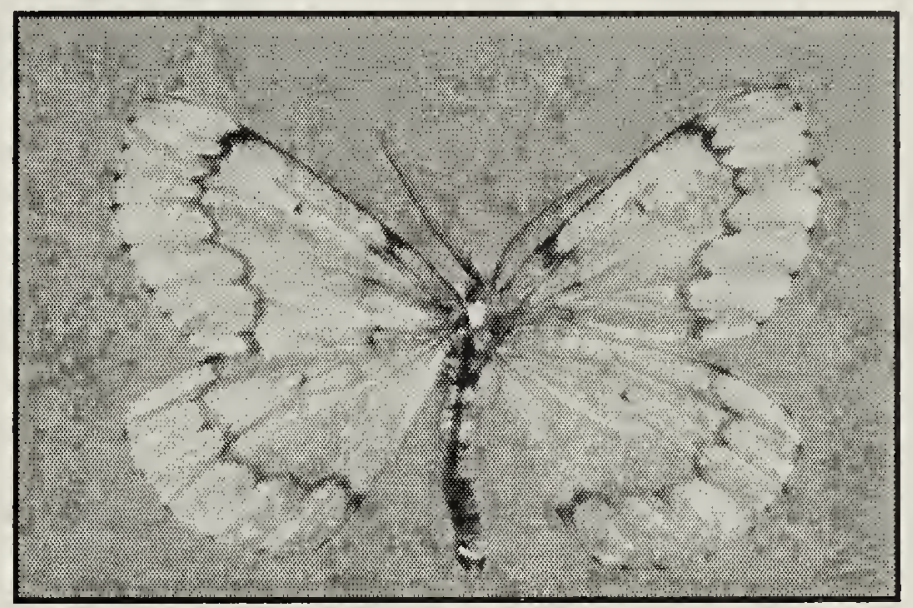

Chain-dotted Geometer

RSM collection, Keith Roney

False Hemlock Looper Nepytia canosaria (Walker) - Central Sask., n. to Cumberland House area and Nemeiben Lake; s. to Fort Qu'Appelle area. (28-30 $\mathrm{mm}$ ) (Aug. 13-28) Reported on fir, spruce, tamarack and pine.

Hemlock Spanworm Lambdina fiscellaria (Gn.) - Central Sask., n. to Sturgeon Landing and La Ronge area; s. to Fort Qu'Appelle and Buffalo Pound Provincial Park; also at Wood Mountain Regional Park. (28-36 mm) (Aug. 26Sept. 27) Reported on fir, spruce, tamarack, birch, pine and aspen.

Curve-lined Looper Lambdina fervidaria athasaria (Walker) - Tantallon. (32 mm) (June 14) Reported on maple and birch. 
Straw Besma Besma endropiaria (G.\&R) - N. Sask., s. to Candle Lake area. (31-33 mm) (July 4) Reported on birch.

Oak Besma Besma quercivoraria (Gn.) - N. Sask., s. to Moose Mountain Provincial Park and Harlan area. (31$34 \mathrm{~mm}$ ) (May 31- July 8) Reported on birch and willow.

Canary Thorn Neoterpes triangulifera (Pack.) - Milliken Lake (on a rock outcrop) (specimen in CNC) Reported on gooseberry and currant.

Pink-bordered Yellow Sicya macularia (Harr.) - S. Sask., n. to Otter Rapids. (30-33 mm) (July 3- Aug. 17) Reported on aspen, willow and alder.

Sage-brush Girdle Plataea trilinearia (Pack.) - S.w. Sask., e. to Roche Percee; n. to Estevan, Buffalo Pound Provincial Park, Outlook and Tramping Lake Regional Park. (30-34 mm) (May 27July 19) Flies among sagebrush.

Twin-spot Girdle Caripeta divisata Walker - Central Sask., n. to Montreal Lake area; s. to Weyburn area. (29-35 $\mathrm{mm}$ ) (June 25- July 9) Reported on spruce, fir and tamarack.

Oblique Girdle Caripeta angustiorata Walker) - N. Sask., s. to Weyburn area. (30-36 mm) (June 24- July 17) Reported on pine and spruce.

Northern Pine Looper Caripeta piniata (Pack.) - Reported for Moosomin area and Regina area. Reported on pine and spruce.

October Thorn Synaxis jubararia (Hulst) - S. Sask., n. to Norquay, Saskatoon and Harlan area. (38-47 mm) (Aug. 4-Sept. 26) Reported on willow, alder, birch and aspen.
Oblique Thorn Tetracis cachexiata Gn. - S. Sask., n. to Ruby Lake and Saskatoon area. (35-45 mm) (May 29July 7) Reported on alder, willow, birch and tamarack.

Yellow Slant-line Tetracis croccalata Gn. - S. Sask., n. to Cumberland House. and Narrow Hills Provincial Park. (35$41 \mathrm{~mm}$ ) (May 31- July 18) Reported on willow and alder.

\section{Large Maple Spanworm} Prochoerodes lineola (Goeze) $(=P$. transversata (Drury)) - S. Sask., n. to Shoal Lake, Red Earth, Waskesiu area and Meadow Lake Provincial Park. (39$43 \mathrm{~mm}$ ) (July 15- Sept.4) Reported on aspen, fir, birch, willow, poplar and maple.

Variable Antepione Antepione thisoaria (Gn.) - Maryfield, Moose Mountain, Tantallon and Fort Qu'Appelle. (33-38 mm) (May 25- June 25) Reported on alder and maple.

Curve-toothed Geometer Eutrapela clemataria (J. E. Smith) - E. Sask., n. to Sturgeon Landing, w. to Turtleford area. (39-50 mm) (May 25- June 27) Reported on dogwood, cherry, willow and bog myrtle.

Confused Eusarca Eusarca confusaria Hbn. - Roche Percee and Crooked Lake. (34 mm) (June 26) Reported on aster, dandelion, goldenrod and clover.

Snowy Geometer Eugonobapta nivosaria (Gn.) - Fort Qu'Appelle. (27$29 \mathrm{~mm}$ ) (July 3-31) Reported on dogwood and chokecherry.

\section{Bordered Thorn (Horned} Spanworm) Nematocampa resistaria (H.-S.) (=N. limbata (Haw.)) - S. Sask., n. to Otter Rapids. (19-26 mm) (June 
26-Aug. 20) Reported on fir, willow, spruce, birch and tamarack.

\section{EXPECTED SPECIES}

\section{Small Purplish Gray Iridopsis} humaria (Gn.) (=Anacamptodes humaria) - Eastern Canada, west to Fort McMurray, Alberta.

\section{ACKNOWLEDGEMENTS}

I thank Klaus Bolte of Ottawa for checking the identification of most of our Geometrid species. I also thank Greg Pohl of Edmonton for checking this manuscript and giving helpful suggestions.

1. COVELL, C. V., Jr., 1984-A Field Guide to the Moths of Eastern North America. Houghton Mifflin Co., Boston. (Well illustrated)

2. JONES, R. J. L., 1951. An Annotated Checklist of the Macrolepidoptera of British Columbia. Occasional Paper No.1, Entomological Society of British Columbia.
3. MCGUFFIN, W.C., 1977. Guide to the Geometridae of Canada II Subfamily Ennominae 2. Memoirs of the Entomological Society of Canada No. 101. (Well illustrated).

4. MCGUFFIN, W. C., 1981. Guide to the Geometridae of Canada II Subfamily Ennominae 3. Memoirs of the Entomological Society of Canada No. 117. (Well illustrated).

5. MCGUFFIN, W. C., 1987. Guide to the Geometridae of Canada II Subfamily

Ennominae 4. Memoirs of the Entomological Society of Canada No. 138. (Well illustrated).

6. PRENTICE, R.M. 1963. Forest Lepidoptera of Canada: Recorded by the Forest Insect Survey. Vol. 3. Canada Department of Forestry, Ottawa, Ontario.

7. SCROBLE, M J., (Ed.) 1999. A Taxonomic Catalogue to the Geometridae of the World. 2 Vols., CSIRO Publications, Melbourne.

8. TROUBRIDGE, J. and LAFONTAINE, D., The Moths of Canada, 2003, website:

http://www.cbif.gc.ca/spp_pages/misc_moths/ phps/mothindex_e.php

"The sight of a large and conspicuous plasmodium can sometimes excite people who are not familiar with myxomycetes [slime molds]. An unusually spectacular mass appearance of the plasmodia of Fuligo septica in a suburb of Dallas, Texas, even made the news nationwide in the United States in 1973. The plasmodia of $F$. septica are usually bright yellow and often spread over large areas. The sudden, unexplained appearance of these 'pulsating yellow blobs' in lawns and other similar situations caused a virtual panic among some of the local inhabitants. The blobs broke apart when blasted with water, but the pieces continued to crawl about and increase in size."

Steven L. Stephenson and Henry Stempen, 2000, Myxomycetes, A Handbook of Slime Molds, p.67. 